Original Research

\title{
Effects of Combined Nitrogenous Based Inorganic Fertilizers and Two Forms of Organic Fertilizers on Plant Phenotypic Characteristics and Soil Bacterial Community Structure within a Cotton Field Environment
}

\author{
Xiaogang Wang, Jiaohai Zhang, Songbo Xia, Hongde Qin, Changhui Feng, \\ Youchang Zhang, Shu Bie*
}

Institute of Cash Crops, Hubei Academy of Agricultural Sciences / Key Laboratory of Cotton Biology and Breeding in the Middle Reaches of the Changjiang River, Ministry of Agriculture, Wuhan, Hubei, China.

Received: 26 November 2019

Accepted: 8 March 2020

\begin{abstract}
The purpose of the study is to unravel the effects of inorganic Nitrogen $(\mathrm{N})$ combined with either organic fertilizer or biochar on the soil biochemical properties, plant phenotypic characteristics and soil bacterial community structure within an experimental cotton field. The experiment involved the determination of the soil chemical properties, enzymatic activities and bacterial community. The study method employed field measurements, laboratory analyses, high throughput sequencing of the bacterial $16 \mathrm{~S}$ rDNA to examine the response of soil enzymatic activities, microbial communities and plant phenotypic properties to the applied three different fertilizer regimens; (1) inorganic fertilizer (N), (2) $\mathrm{N}+$ organic fertilizer $(\mathrm{N}+\mathrm{OF}),(3) \mathrm{N}+$ biochar fertilizer $(\mathrm{N}+$ Biochar), under two cotton varieties: CN01 and ZD2040. The study indicated that combined N plus carbon-based organic fertilizer is responsible for enhanced crop growth, yield productivity and probiotic soil microbial content. Further, the combined mineral and carbon-based fertilizer regimen is highly beneficial to soil microbial content and diversity. The occurrence could be due to the increased soil nutrient content as a result of availability of carbon-based fertilizer and induced microbial activity by the mineral fertilizer. The use of $\mathrm{N}$ plus carbon-based organic fertilizer is recommended to improve the soil quality and cotton yield.
\end{abstract}

Keywords: inorganic fertilizers, microbial community structure, nitrogenous fertilizer, organic fertilizer, phenotypic traits

*e-mail: Bieshu2019@163.com 


\section{Introduction}

High and increasing global demand for agricultural produce has put a strain on crop production. Consequently, this situation has led to dependency in intensive agricultural management practices. Fertilizer application is a key farming practice that has been used over a long period of time in improving crop nutrition and productivity through availing of nutrients to plants, with associated soil property and microbial changes [1], and its use is expected to continuously increase in the coming decades. Application of these fertilizers, either organic or inorganic, not only impact on the plants' growth and health, but also influence the soil nutrient availability, physico-chemical properties, plant diseases suppression, disease incidence and soil microbiota [2-4].

With respect to agricultural sustainability and cropping systems, soil microbial processes are of high significance because of their essential role in the dynamics of soil carbon (C) and N [5]. Application of organic fertilizer amendments has been found to improve soil fertility, soil structure and microbial biomass through the increase of soil nutrient and organic matter content [6-8]. Organic fertilizers contribute in the enrichment of soil microbial biomass through their supply of C-rich organic compounds to the C-limited soil microbial communities [9]. Additionally, the availability of $\mathrm{C}$ in the soil tend to favor proliferation of specific microbial groups that utilize organic compounds, hence changing general soil microbial community structure [10]. Several conducted studies estimate that soil microbial activity increases by $16 \%$ to $20 \%$ when organic fertilizer is applied, compared to inorganic fertilizers $[8,6,11,13]$. Further, an increase in enzymatic activities associated with plant macronutrients in relation to organic fertilizers has been recorded in some studies [11, 14]. Therefore, soil amendments by organic fertilizer can promote soil microbial activities and subsequently give high crop yields due to the increase in long term soil organic matter and soil fertility, when compared to inorganic fertilizer amendments $[15,16]$. However, a study had illustrated that the application of organic fertilizer can improve plant growth and yields even in cases when they are applied in small quantities in a single planting season [17-19].

Equally, inorganic fertilizers like the $\mathrm{N}$ fertilizer have had an impressive contribution in improving crop yields [20]. Indeed, different forms of nitrogenous fertilizers have been used singly in agricultural farms to increase productivity [21]. In addition, most cotton farmers have resorted to the use of soil conditioning techniques to help restore soil integrity and consequently improve cotton productivity [22]. Contrary to the positive contribution of nitrogenous fertilizer to increased crop productivity, some of them have been shown to pose consequential effects on the soil microbial diversity and community structure, a condition that results to alteration in the soil enzymatic activities [23]. Such consequential effects may be based on the relationship that exists between the soil microbial communities and the soil enzyme activities $[20,24]$. Further, the application of inorganic fertilizers over a long period of time can also present negative effects on overall soil quality as a result of complex $\mathrm{N}$ transformation in the soil, soil acidification, breakdown of soil structure, and decline in soil productivity [3].

Therefore, a field experiment was undertaken with cotton as the crop of production. This study was purposed to unravel the effects of various fertilizer treatments on soil ecosystems and plant phenotypic and enzymatic characteristics. Jingzhou city in Hubei Province was chosen as the study location because it is a major agricultural zone in China and the soil ecosystem is highly evolved due to agricultural practices and soil management regimes. Soil management practices have a major impact on the crop growth, yields and soil microbial communities. The study hypothesized that combining $\mathrm{N}$ and carbon-based organic fertilizer does not add any significant contribution on the growth, yield productivity of cotton as well as on the probiotic soil microbial content based on the prevailing soil conditions within the Jingzhou agricultural zone of the people's republic of China. The study employed the use of high throughput sequencing of the bacterial $16 \mathrm{~S}$ rDNA, together with other experimental approaches in examining the response of soil microbial communities and plant phenotypic properties to three different fertilizer regimens; i.e. $\mathrm{N}, \mathrm{N}+$ Organic fertilizer and $\mathrm{N}+$ Carbon-based organic fertilizer, applied on CN01 and ZD2040 cotton varieties. The two cotton varieties are superior cotton varieties that can produce high and stable yields under low chemical fertilizers, pesticides and water, and are more tolerant to pests, diseases, drought, salinity, submergence and other abiotic or biotic stresses, but slightly differed in amylose and protein content [25].

\section{Materials and Methods}

\section{Experimental Site and Study Setup}

A field experiment was set-up in a cotton field in Hubei province, China $\left(111^{\circ} 48^{\prime} \mathrm{E}, 29^{\circ} 37^{\prime} \mathrm{N}\right)$. The study region has a typical subtropical climate with annual precipitation of $1200 \mathrm{~mm}$, annual evaporation stands at $600 \mathrm{~mm}$ and the average temperature is 16-17 ${ }^{\circ} \mathrm{C}$ (Source: http://www.hubei.gov.cn/). The studied soil used in cotton production was fluvisol, based on Food Agricultural Organization (FAO) classification guidelines. The studied crop system comprised of two varieties of cotton. Three fertilization treatments were applied: (1) inorganic fertilizer $(\mathrm{N}),(2)$ organic fertilizer $(\mathrm{N}+\mathrm{OF})$, (3) biochar fertilizer ( $\mathrm{N}+$ Biochar), all with two varieties: CN01 and ZD2040. Unfertilized soil was used as control. Each fertilizer treatment was performed in triplicate in a field area of $30.4 \mathrm{~m}^{2}$; 
with a plant spacing of $22 \mathrm{~cm}$ and eventual density of 3987 plants/ha, in a randomized block design (Table 1). Each treatment was applied on the same day. The regular fertilizer application rates of $\mathrm{N}, \mathrm{P}$, and $\mathrm{K}$ were the same for each treatment $\left(10 \mathrm{~kg} \mathrm{ha}^{-1}\right)$. The compound fertilizer: $\left(\mathrm{N}-\mathrm{P}_{2} \mathrm{O}_{5}-\mathrm{K}_{2} \mathrm{O}\right)(25-10-16)$ was obtained from Hubei Xinyang Fengfei Company Ltd (Hubei Xinyang Fertilizer Co, Ltd, China), organic fertilizer $\left(\mathrm{N}-\mathrm{P}_{2} \mathrm{O}_{5}-\mathrm{K}_{2} \mathrm{O}\right)$ (13-8-9) with organic matter content of $\geq 15 \%$ was obtained from Zhongnong Fertilizer Co, ltd, China, while the biochar-based organic fertilizer $(1 \#)$ : $\mathrm{C}=10 \%$, total nutrient $\geq 5 \%$ (calculated by $\mathrm{N}-\mathrm{P}_{2} \mathrm{O}_{5}-\mathrm{K}_{2} \mathrm{O}$ with 2-2-2), organic matter content $\geq 5 \%$ was obtained from Hennan Huinong Fertilizer Co, Ltd, China. The fertilization level was $\mathrm{N}-\mathrm{P}_{2} \mathrm{O}_{5}-\mathrm{K}_{2} \mathrm{O}=2.5-1.52-1.71$. The specific fertilizers and dosages are as shown in Table 1.

\section{Chlorophyll Content, Photosynthetic and Yield Parameters}

Chlorophyll content was measured using the spectrophotometry method. Net photosynthetic rate was measured through the increase in dry mass which was undertaken through the technique of 'serial harvests' where cotton leaves were harvested, dried to constant weight and weighed - this was repeated over the duration of the experiment. Stomatal conductance and transpiration rate were measured using a steady state potometer which measures stomatal conductance using a sensor head with a fixed diffusion path to the leaf. It measures the vapor concentration at two different locations in the diffusion path. It computes vapor flux from the vapor concentration measurements and the known conductance of the diffusion path. Intercellular carbon dioxide concentration was determined through the direct measurement of intercellular $\mathrm{CO}_{2}$ concentration in a gas-exchange system. Root weight, cotton ball weight, ratio of root to shoot and yield of un-ginned cotton were measured for each cotton variety under each treatment.

\section{Soil Chemical Properties and Enzymatic Activity}

Sampling of soil in all the treatments was performed at the boll-opening stage of cotton development. Random soil sampling was done in replicates of 10 in a range of $5 \mathrm{~cm}$ from the cotton trunk at soil depths of 0-15 cm. Thereafter, all the replicates were completely mixed to produce a uniform and homogenous sample. The soil samples were then were transported to the lab in ice box under cold condition and all the physicochemica parameters analyzed within a week from the collection time. One part of all study samples was cryopreserved $\left(-80^{\circ} \mathrm{C}\right)$ for later use in soil microbiological and chemical analysis. Soil chemical properties were analyzed as described by Liu [26]. In brief, soil total $\mathrm{N}$ was determined by Kjeldahl digestion. Soil available $\mathrm{N}$ was converted to $\mathrm{NH}^{+}{ }_{4}$ under alkaline conditions, collected in a $\mathrm{H}_{3} \mathrm{BO}_{3}$ solution, and subsequently, determined by titration with standard $0.01 \mathrm{~mol} \mathrm{~L}^{-1} \mathrm{H}_{2} \mathrm{SO}_{4}$. Total soil $\mathrm{P}$ was measured by first digesting soil in a mixed acid solution of $\mathrm{H}_{2} \mathrm{SO}_{4}$ and $\mathrm{HClO}_{4}$, and then, analyzed by the molybdo-phosphate method. Available soil P was determined by the Olsen method. Soil $\mathrm{pH}$ was measured in 1:2.5 soil:water slurry using a glass electrode. The determination of Urease, Nitrate reductase and Nitrite reductase tests were conducted as previously described [27]. Experimental analysis of all enzymatic activities was conducted in triplicates for all the soil samples.

Total Microbial DNA Extraction, PCR Amplification and 16S rDNA Sequencing

Total DNA was extracted from all the treatments, each comprising of a homogeneous mixture of the replicate samples for each treatment. Approximately, 0.4 grams of soil samples was used in DNA extraction using the E.Z.N.A. ${ }^{\circledR}$ soil DNA Kit (Omega BioTech, Norcross, GA, U.S.) based on the manufacturer guidelines. Briefly, the soil sample and solution were added to a sterile Eppendorf tube then vortexed for 15 seconds at $5000 \mathrm{r} \mathrm{min}{ }^{-1}$. The resultant supernatant

Table 1. Table of fertilizer application rates under cotton variety CN010 and ZD2014.

\begin{tabular}{|c|c|c|c|c|c|c|}
\hline Variety & Treatment & $\begin{array}{l}\text { Compound } \\
\text { fertilizer } \\
\left(\mathrm{Kg} \mathrm{ha}^{-1}\right)\end{array}$ & $\begin{array}{l}\text { Organic } \\
\text { Fertilizer } \\
\left(\mathrm{Kg} \mathrm{ha}^{-1}\right)\end{array}$ & $\begin{array}{c}\text { Carbon-based } \\
\text { organic fertilizer } \\
\left(\mathrm{Kg} \mathrm{ha}^{-1}\right)\end{array}$ & $\begin{array}{l}\mathrm{P}_{2} \mathrm{O} \text { Make up } \\
\left(\mathrm{Kg} \mathrm{ha}^{-1}\right)\end{array}$ & $\begin{array}{l}\mathrm{K}_{2} \mathrm{O} \text { Make up } \\
\quad\left(\mathrm{Kg} \mathrm{ha}^{-1}\right)\end{array}$ \\
\hline \multirow{3}{*}{ CN01 } & $N$ & 10 & - & - & 3.25 & 0.18 \\
\hline & $N+$ organic fertilizer & - & 19 & - & - & - \\
\hline & $\begin{array}{c}N+\text { carbon based organic } \\
\text { fertilizer }\end{array}$ & 8.4 & - & 20 & 1.75 & - \\
\hline \multirow{3}{*}{ ZD2040 } & $N$ & 10 & - & - & 3.25 & 0.18 \\
\hline & $N+$ organic fertilizer & - & 19 & - & - & - \\
\hline & $\begin{array}{c}N+\text { carbon based organic } \\
\text { fertilizer }\end{array}$ & 8.4 & - & 20 & 1.75 & - \\
\hline
\end{tabular}


was transferred to a new Eppendorf tube as described in the manufacturer's extraction protocol. Final DNA elute was aliquoted into three parts and stored at $-20^{\circ} \mathrm{C}$ until use. To check for quality, the extracted genomic DNA was checked using 1\% agarose gel electrophoresis. Ethidium bromide $\left(5 \mu \mathrm{g} \mathrm{mL}^{-1}\right)$ was used in staining the agarose gel and the image viewed on a gel imaging system. The extracted genomic DNA was used as PCR amplification template of the V3-V4 hypervariable regions of the 16SrDNA gene with previously described universal primers $338 \mathrm{~F}$ (5'-ACTCCTACGGGAGGCAGCAG-3') and 806R (5'-GGACTACHVGGGTWTCTA AT-3') [28]. Briefly, PCR reactions were performed in triplicate $20 \mu \mathrm{L}$ mixture containing $4 \mu \mathrm{L}$ of $5 \times$ FastPfu Buffer, $2 \mu \mathrm{L}$ of $2.5 \mathrm{mM}$ dNTPs, $0.8 \mu \mathrm{L}$ of each primer $(5 \mu \mathrm{M})$, $0.4 \mu \mathrm{L}$ of FastPfu Polymerase and $10 \mathrm{ng}$ of template DNA. The resulted PCR products were extracted from a $2 \%$ agarose gel and further purified using the AxyPrep DNA Gel Extraction Kit (Axygen Biosciences, Union City, CA, USA) and quantified using QuantiFluor ${ }^{\mathrm{TM}}$ -ST (Promega, USA) according to the manufacturer's protocol. For DNA sequencing, TruSeqTM DNA Sample Prep Kit was used. In every sample, Purified amplicons were pooled in equimolar and paired-end sequenced $(2 \times 300)$ on an Illumina MiSeq platform (Illumina, San Diego,USA) according to the standard protocols by Majorbio Bio-Pharm Technology Co. Ltd. (Shanghai, China).

\section{Data Sequence Editing, Categorical Transformation}

The obtained sequenced data was edited, categorized based on similarity and thereafter classified. In brief, all low-quality reads below a Phred score of 28 , sequencing tags, chimeras and non-bacterial ribosomal sequences were filtered from the dataset, using the MOTHUR software package [29]. Thereafter, the paired-end reads were merged with an allowed minimum overlap of 10bp. A second tier of quality control and filtering was performed and then operational taxonomic units (OTU) were assigned to the sequences with a cutoff of $95 \%$ similarity. OTUs with reads $\geq 3$ were filtered out as they may be a result of sequencing artifacts [30]. Bacterial 16S OTU classification was done against the non-aligned version of Silva database.

\section{Statistical Analysis}

Data was analyzed using MINITAB statistical package version 14 (https://www.minitab.com/en-us/ products/minitab/), QIIME and $\mathrm{R}$ software. Mean differences were calculated at a $\mathrm{p}$ value of 0.05 . Means were compared using one-way Analysis of Variance (ANOVA) and Least Significant Test (LSD) used in mean separation as a post hoc test. All the statistical tests performed in this study were considered significant at $\mathrm{P}<0.05$.

\section{Results}

\section{Chlorophyll Content, Photosynthetic and Yield Parameters}

The results on chlorophyll content, photosynthetic and yield parameters are provided in Fig. 1. The chlorophyll content and photosynthetic parameters showed a similar trend across all the fertilizer applications and the cotton varieties. The net photosynthetic rate, stomatal conductance, intercellular carbon dioxide concentration $(\mathrm{Ci})$, and transpiration rate were all observed to be highest on the $\mathrm{N}+$ Carbonbased organic fertilizer application than the other two fertilizers applications ( $\mathrm{N}$ fertilizer and the $\mathrm{N}+$ Organic fertilizer applications) under both the two cotton varieties (CN01 and ZC2040) (Fig. 1a). Yield parameters also showed similar trend, the root weight, cotton ball's weight, ratio of root to shoot and yield of unginned cotton were all highest on the $\mathrm{N}+$ Carbon-based organic fertilizer application than the other two fertilizers applications ( $\mathrm{N}$ fertilizer and the $\mathrm{N}+$ Organic fertilizer applications) under both the two cotton varieties (CN01 and ZC2040). However, there was a slight change of trend for the ratio of root to shoot under the ZC2040 variety, which showed significantly similar values across all the fertilizer applications (Fig. 1b).

\section{Soil Biochemical Properties}

The results on enzymatic activities in $\mu$ mole $/ \mathrm{min} / \mathrm{mg}$ are provided in Fig. 2. The urease activity for both the CN01 and ZC2040 cotton varieties was highest at the $\mathrm{N}+$ Organic fertilizer application than on the $\mathrm{N}$ fertilizer and the $\mathrm{N}+$ Organic fertilizer applications. The nitrate reductase enzymatic activity was equally highest at the $\mathrm{N}+$ Organic fertilizer application than on the $\mathrm{N}$ fertilizer and the $\mathrm{N}+$ Organic fertilizer applications. However, the Nitrite reductase activity was highest on $\mathrm{N}+$ Carbon-based organic fertilizer application than the other fertilizer application under the CN01 cotton variety but highest on the $\mathrm{N}$ fertilizer application under the ZC2040 cotton variety.

\section{Bacterial Diversity and Community Composition}

The bacterial community operation taxonomic units through pieplot analysis is shown in Fig. 3. A total of 1,075,591 sequences was obtained after quality check and trimming processes, with an average base length of 440 . Using pie plot, bar plot, and sunburst plot, abundance analysis to identify OTUs comparison and variation across the fertilization treatments was conducted. Unfertilized soil was used as control. OTU $152(9.39 \%)$ was the most dominant bacterial community in all the treatments, followed second by OTU $126(6.16 \%)$ and third was OTU 27 (4.59\%). The percentage of absolute abundance of bacterial 

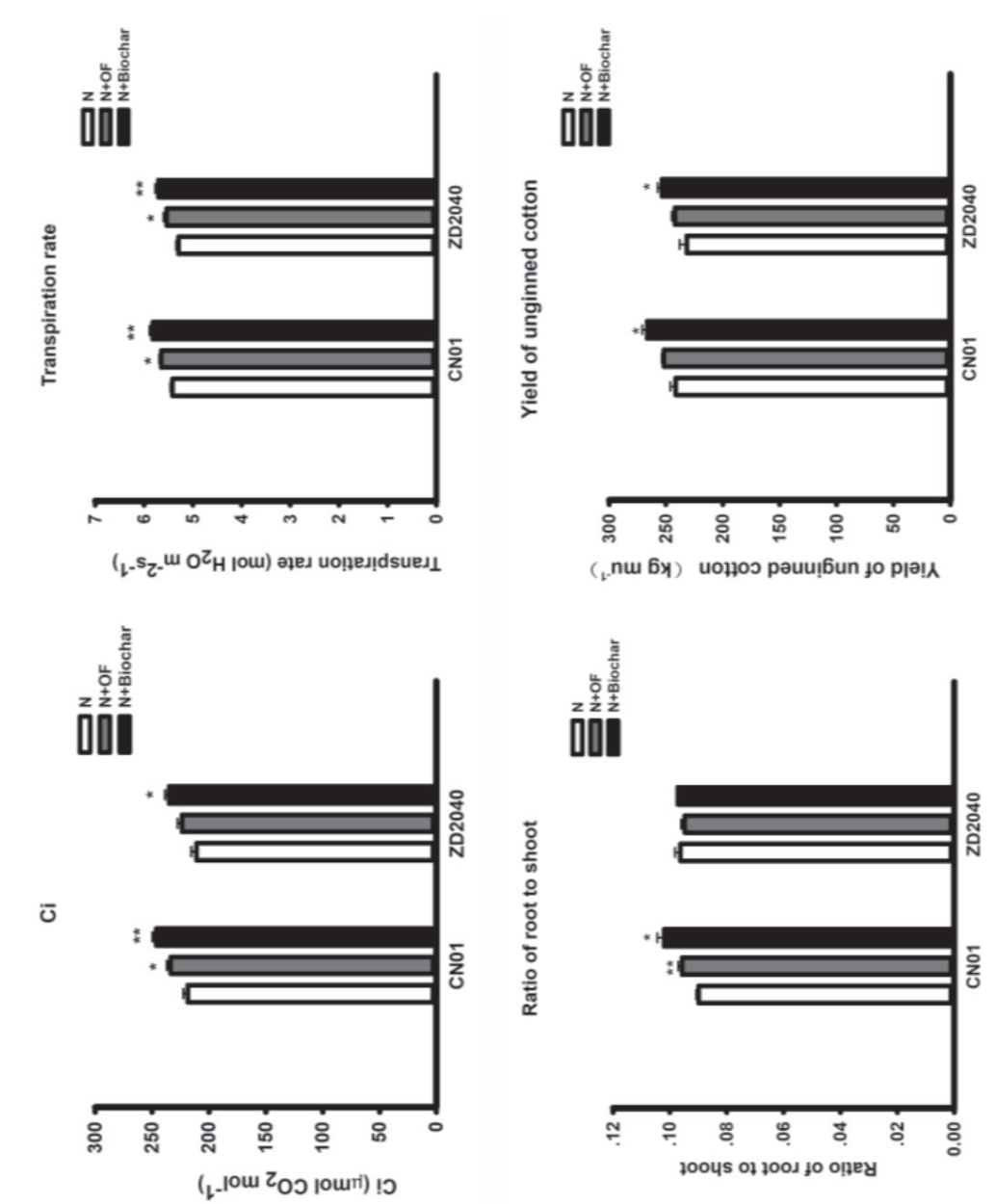

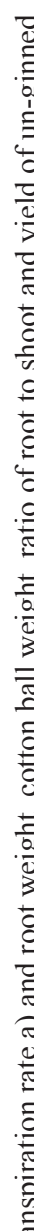
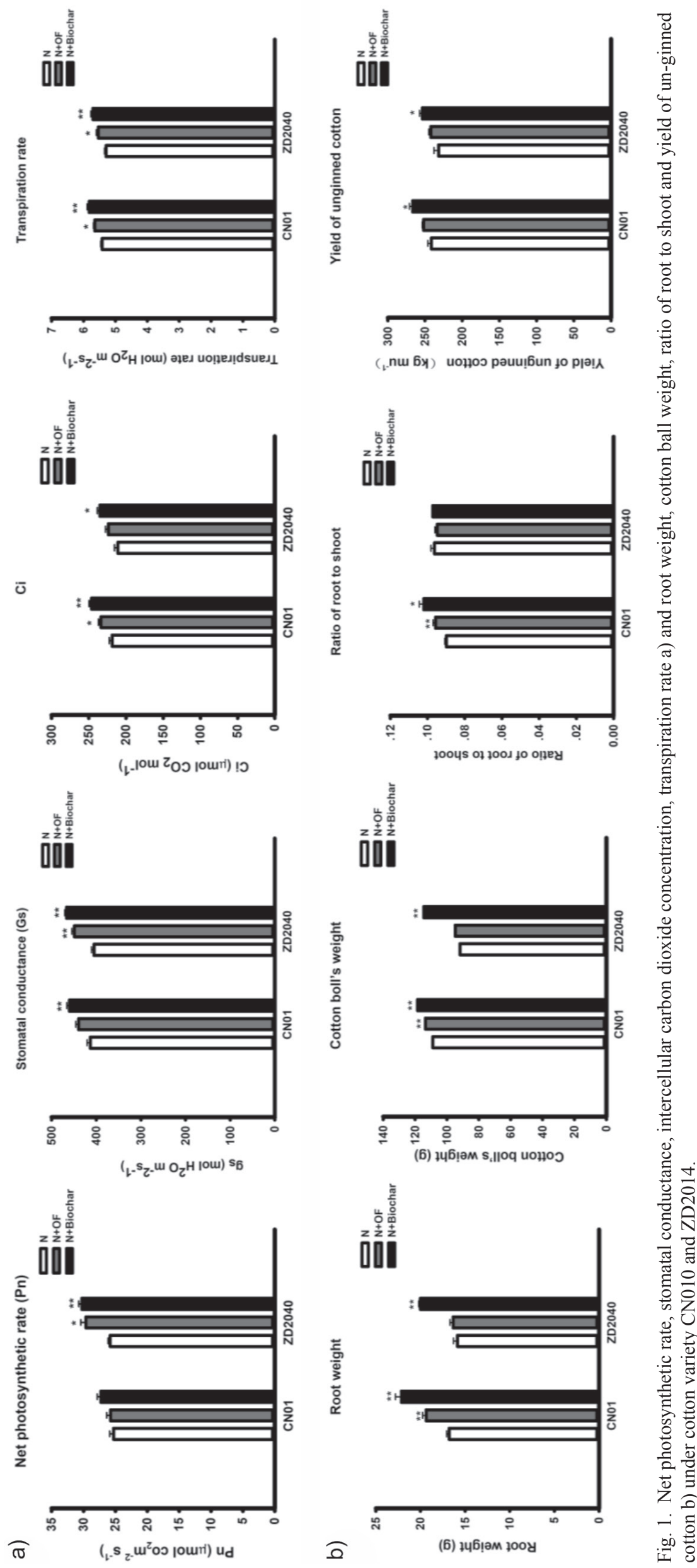

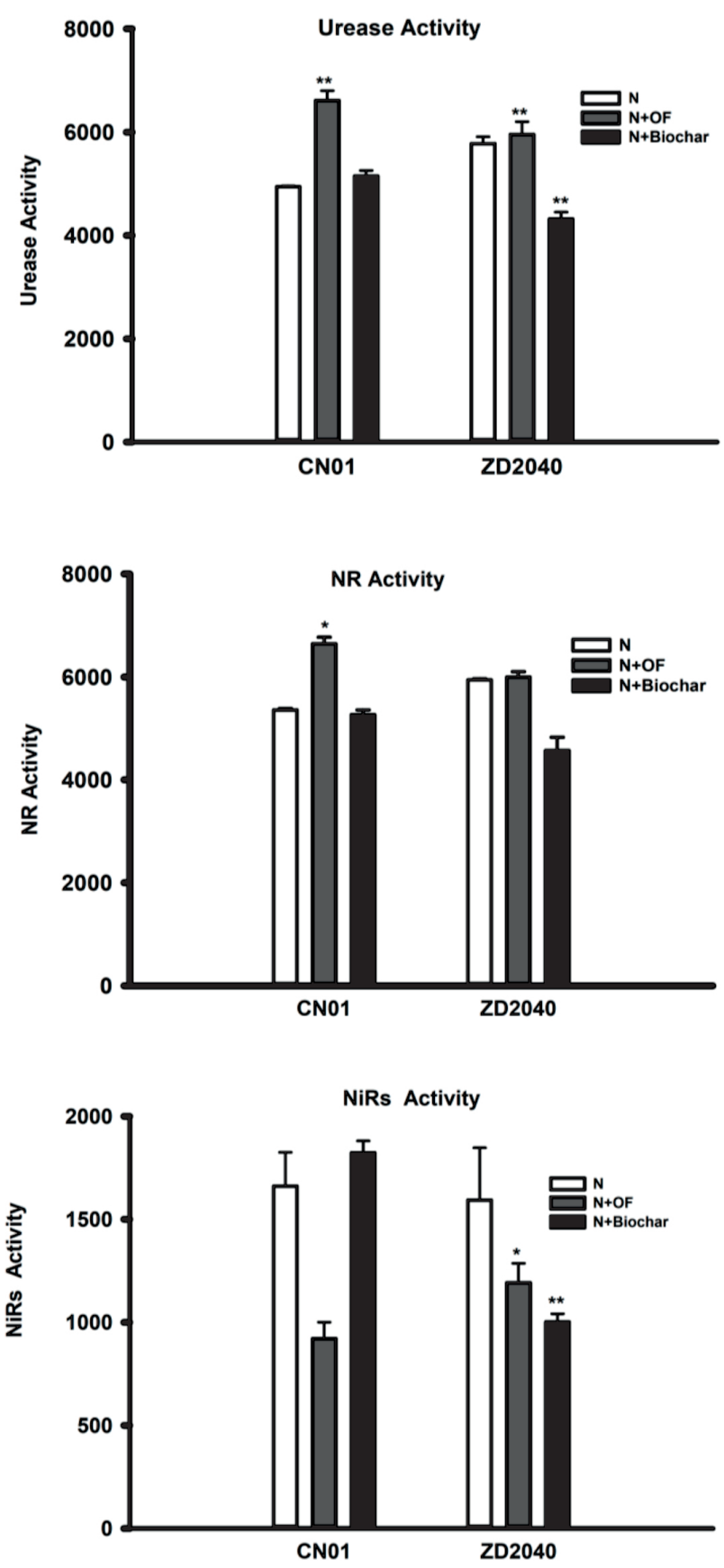

Fig. 2. Soil urease, nitrate reductase (NR) and nitrite reductase (NiRs) enzymatic activities in $\mu \mathrm{mole} / \mathrm{min} / \mathrm{mg}$ under cotton variety CN010 and ZD2014.

community OTU levels through barplot analysis across the treatments is provided in Fig. 4. The result showed that the bacteria of OTU 152 had the highest absolute abundance level in tests $1,2,3$ and 4 while the bacteria of OTU 126 had the highest absolute abundance level in the control tests while almost missing in the other treatment tests. Result on the bacterial community OTU levels across the treatments through sunburst plot analysis is provided in Fig. 5. This result showed that the bacterial phyla Bacteroidetes, Proteobacteria and Firmicutes were the most dominant communities across all the fertilizer treatments.

\section{Relationship between Sample and Species}

With the use of circus sample-species relationship visual diagram, the correspondence between study samples and bacterial species was depicted in terms of the dominant species composition ratio per treatment and between the different treatment regimes. Bacterial phyla Bacteroidetes, Proteobacteria, and Firmicutes were the most dominant communities in all the fertilizer treatments. Bacteriodetes and Firmicutes highly corresponded to the test samples as well as the control. Further, compared to the other three dominant phyla, phylum Vernucomicrobia was present in very small proportions than the test samples and control (Fig. 6).

\section{Beta Diversity Analysis}

We examined for the beta diversity between the test samples derived from the three fertilizer regimens (Fig. 7). The microbial community in test 1 was highly related to the control tests while test two was very diverse rooted from the two test groups. (Fig. 7a).

\section{Discussion}

Nitrogen $(\mathrm{N})$ is a very crucial and important nutrient essential in crop yield formation by establishing and sustaining its photosynthetic capacity [11, 31]. Also, the application of additional $\mathrm{N}$ fertilizer is typically essential for crops to attain optimum yields [32-34]. Most studies have confirmed that the addition of organic materials results to the increase in organic carbon, aggregate stability, moisture retention capacity and infiltration rate of the surface soil while reducing the bulk density. Furthermore, the application of inorganic fertilizer alone can drastically decrease the stability of macro aggregates and moisture retention capacity but increased the bulk density values. The annual applications of mixed fertilizers such as the wheat straw and farmyard manure have therefore resulted in higher grain yields of most crops on long term [35]. Studies also suggest that the partial substitution of inorganic fertilizer with organic fertilizers may be one of the sustainable approaches necessary in the sustainable management of soil nitrogen content, and this has been found to promote cotton productivity, and improving nitrogen use efficiency in cotton farmlands [19, 36]. From our study findings, we established that application of a combined $\mathrm{N}+$ carbon-based fertilizer can increase the chlorophyll content of cotton leaves and hence enhance the photosynthetic capacity of cotton leaves. Further, the dry matter weight and root-shoot ratio of cotton plants are higher, which significantly increased the number of bolls per plant and single boll weight of cotton plants; subsequently improving the yields significantly. Further, in the two cotton varieties (ZD2040 and CN01), stomatal conductance, intercellular 


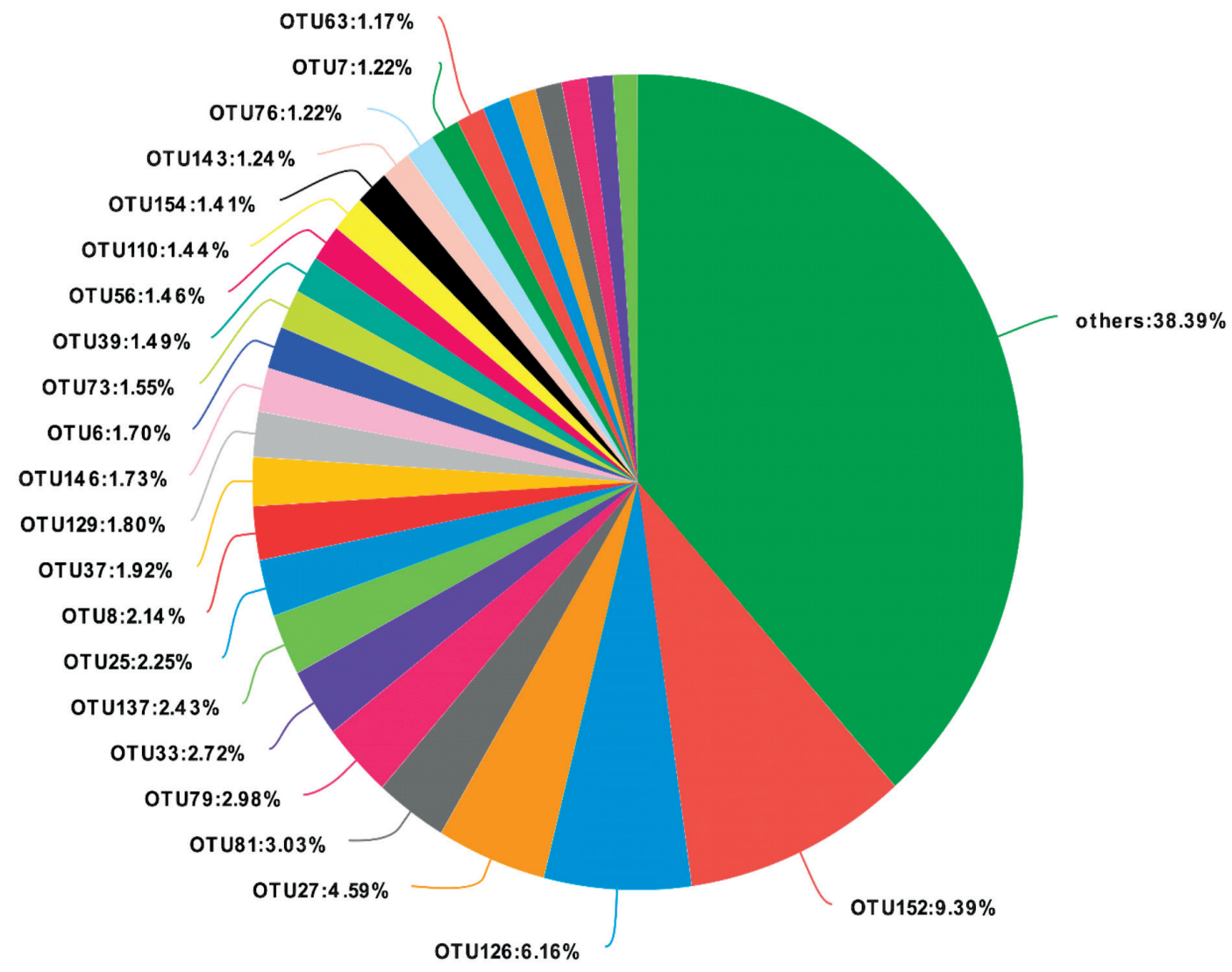

Fig. 3. Bacterial community operation taxonomic units through pieplot analysis.

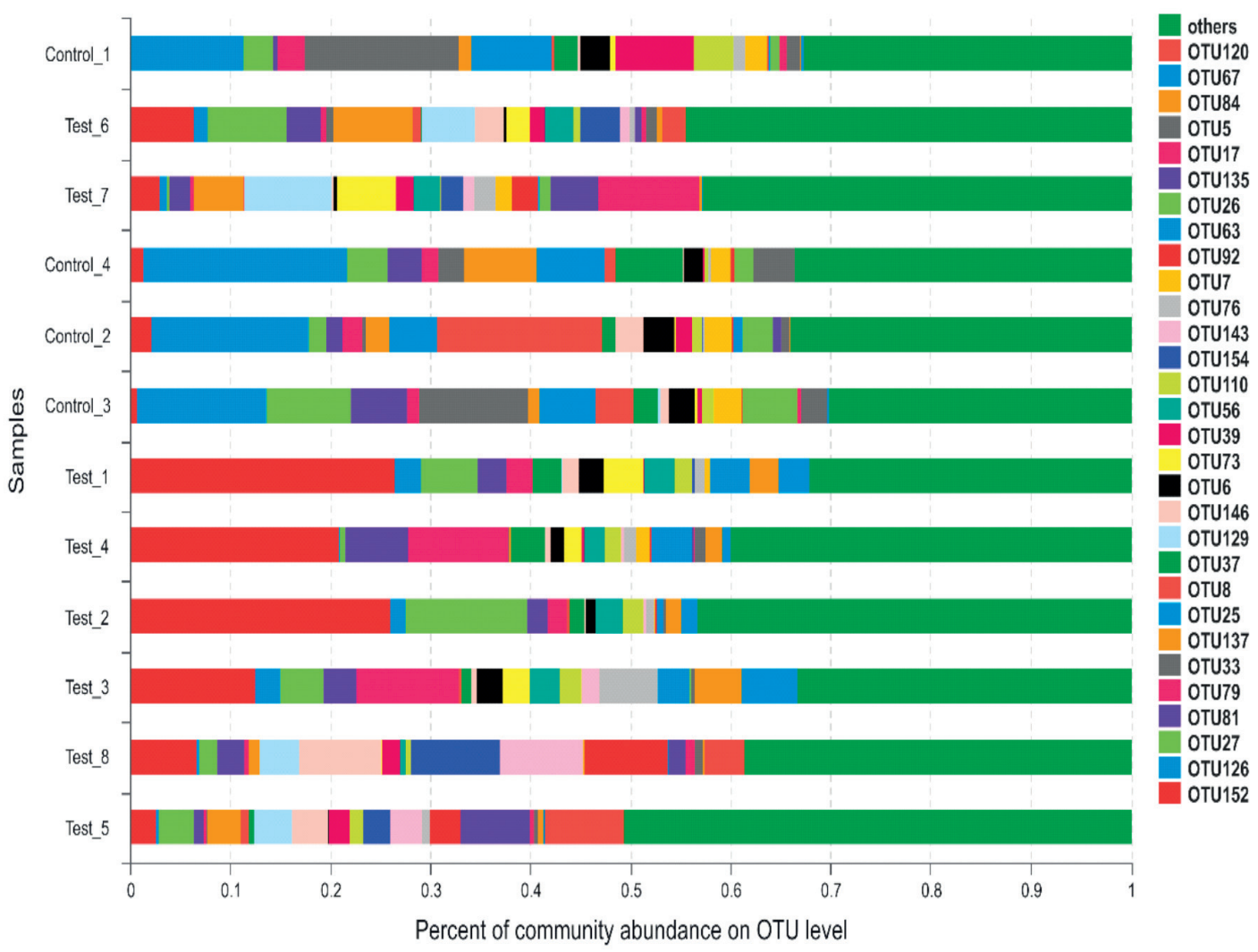

Fig. 4. Percentage of absolute abundance of bacterial community operation taxonomic unit levels across the treatments through barplot analysis. 


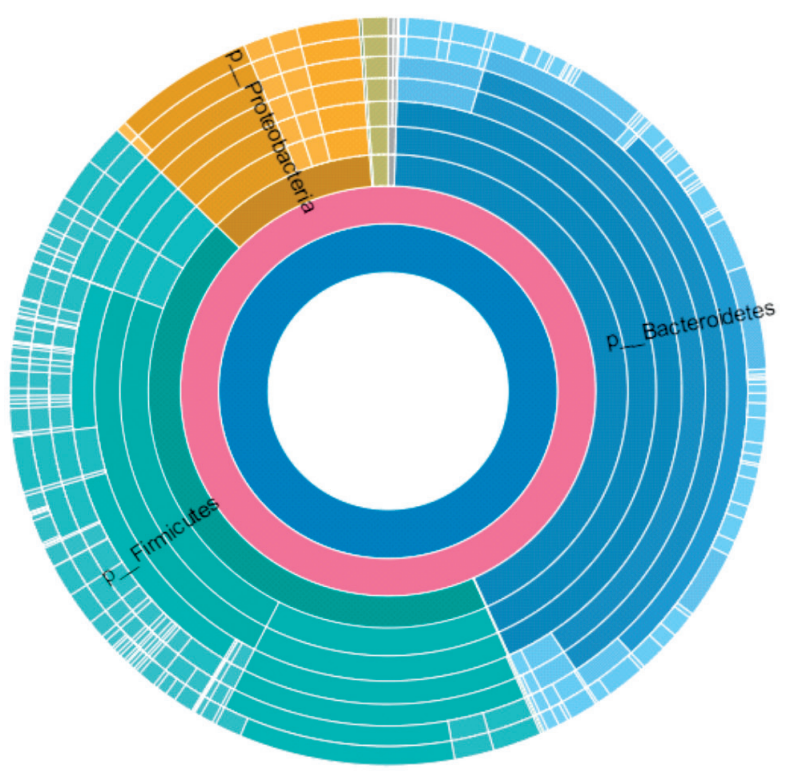

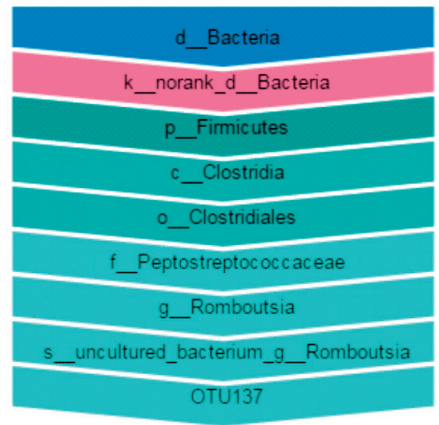

$2.38 \%$

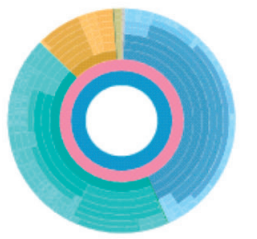

Fig. 5. Bacterial community operation taxonomic unit levels across the treatments through sunburst plot analysis.

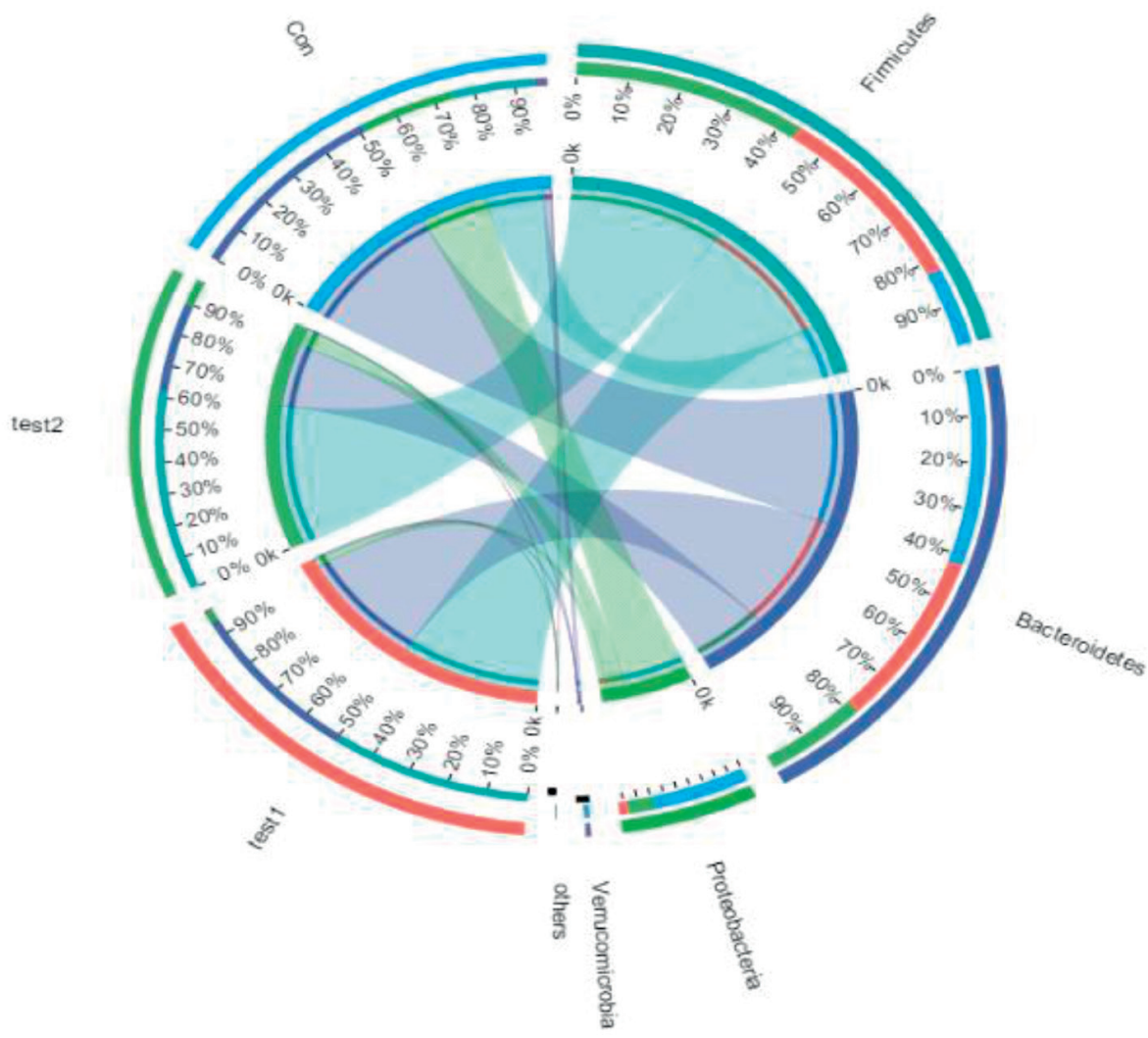

Fig. 6. Sample-species relationship diagram through Circos analysis.

carbon dioxide concentration, and transpiration rate were higher in $\mathrm{N}+$ carbon-based organic fertilizer treatment than in the pure $\mathrm{N}$ treatment. This can be due to the $\mathrm{C}$ availability in the soil hence the proliferation of microbial community and further conversion of soil nutrients and eventual uptake in plants.
Soil enzymatic activities are usually as a result of the activity of soil microbial flora, hence it is highly influenced by the number and diversity of available microbiota. In agricultural soils, denitrification is a very important process. This process is a facultative anaerobic reaction that sequentially reduces $\mathrm{NO}_{3}-$ to 
a) Hierarchical clustering tree on OTU level

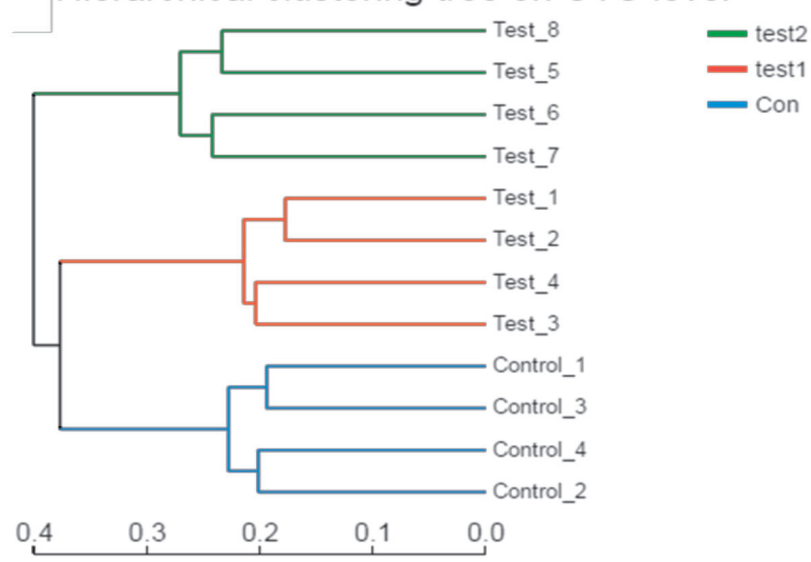

b) Samples distances heatmap on OTU level

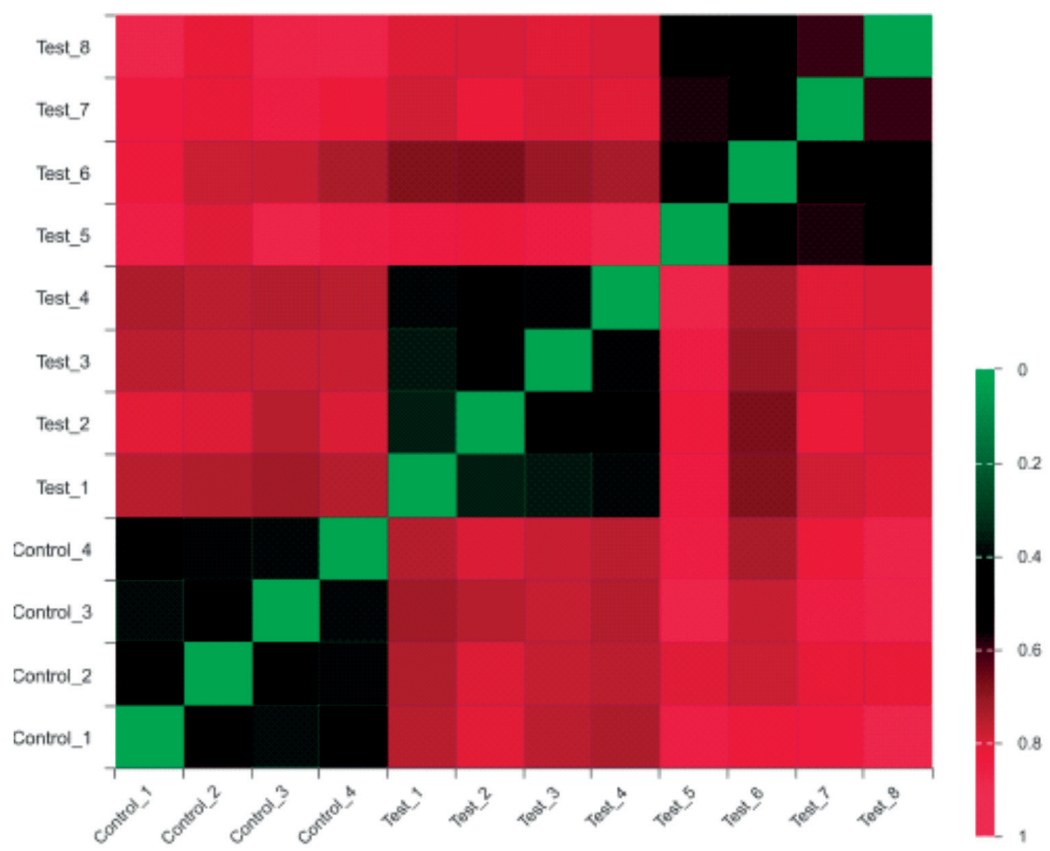

Fig. 7. Beta-diversity analysis of obtained data. a) Hierarchical clustering tree on operation taxonomic unit levels. b) sample distances Heatmap on operation taxonomic unit levels.

$\mathrm{N}_{2}[37,38]$. Nitrate reductase and nitrite reductase are involved in this process. From our study results, we observed the highest enzymatic activity in a combined mix of inorganic and carbon-based organic fertilizer regimen. Enzymatic activities of urease, nitrate reductase and nitrite reductase continuously increased from $\mathrm{N}, \mathrm{N}+$ Organic fertilizer and $\mathrm{N}+$ Carbon-based organic fertilizer, respectively.

Fertilizer amendments often increase the soil organic $\mathrm{C}\left(\mathrm{C}_{\text {org }}\right)$ levels and concentration of other soil nutrients like nitrogen $(\mathrm{N})$ [40]. Soil organic matter sources can be from direct incorporation of manure, straw or sewage sludge or from indirect sources through improved plant growth [41]. Mostly, microbial biomass levels increase with rise in soil $\mathrm{C}_{\text {org }}$ content [42]. Our study findings agree with several previously conducted studies that have shown that organic amendments positively influence microbial biomass [6, 43, 44]. Further, we found bacterial phyla Bacteroidetes, Proteobacteria and Firmicutes (Fig. 4) as being most dominant communities in all the fertilizer treatments, which generally corresponds to previously conducted studies agricultural soil studies [41, 45-47]. In addition, higher OTU diversity was seen in amended soil treatments than in the control group.

With the current advancements in sequencing technologies, it is possible to study soil microbial communities at higher throughput and resolution. Through these platforms, there exist opportunities to evaluate and gauge soil management practices at specific taxa level, and even determine their attributed function. Additionally, in combination with other 
techniques, we can predict fertilizer regimens that promote growth of beneficial microbial flora that in turn translates into positive plant proliferation and hence higher yields [48]. For example, some of the previously conducted studies have reported a negative correlation between Verrucomicrobia abundance available nitrogen, phosphorus and potassium, and soil organic matter $[49,50]$. In that, there is a decrease of Verrucomicrobia communities when levels of available nitrogen, phosphorus and potassium and soil organic matter increase. From our study, there was a small proportion of Verrucomicrobia. These observations depict that new microbial study technologies present novel ways to monitor the level, presence or even absence of different bacterial taxa that can be influenced by varying soil management practices under agricultural production $[50,51]$.

\section{Conclusion}

In conclusion, we used a multidisciplinary approach in studying the effects of combined organic and inorganic fertilizer treatments on soil microbial communities and crop productivity. Combined $\mathrm{N}+$ carbon-based organic fertilizer was shown to be responsible in promoting crop growth, yield productivity and soil microbial content. In comparison to other previously conducted studies, the findings from this present study support the conclusion that the application of carbon-based fertilizer in amalgamation with mineral fertilizer, typically contributes to increased crop productivity and stability. Further, combined mineral and carbon-based fertilizer regimen is highly beneficial to soil microbial content and diversity, this is achieved through increased soil nutrient content as a result of availability of carbon-based fertilizer and induced microbial activity by mineral fertilizer.

\section{Acknowledgements}

The authors are greatly appreciative to the laboratories, the cotton field and the financial agencies that supported the study. This study was supported by funds from the National Key R\&D Program of China (2018YFD0100406) and the China Agriculture Research System (CARS-15-12) and the Agricultural Science and Technology Innovation of Hubei Province (2016-620000-001-010).

\section{Data Availability Statement}

The data that support the findings of this study are available on request from the corresponding author. The data are not publicly available due to privacy or ethical restrictions.

\section{Conflict of Interest}

The authors declare that there is no conflict of interest between them or their various institutions.

\section{Authorship Statement}

Study concept and design: Xiaogang Wang and Shu Bie. Analysis and interpretation of data: Jiaohai Zhang Songbo Xia and Changhui Feng. Drafting of the manuscript: Shu Bie. Critical revision of the manuscript for important intellectual content: Xiaogang Wang, Jiaohai Zhang Songbo Xia Hongde Qin Changhui Feng Youchang Zhang and Shu Bie. Statistical analysis: Xiaogang Wang and Jiaohai Zhang. Obtained funding: Xiaogang Wang and Shu Bie. Study supervision Xiaogang Wang and Shu Bie.

\section{References}

1. ANJAY K., VILAS B., JAYANT D., SUDHIR W. Growth, nutrient uptake and seed cotton yield as influenced by split application of nutrients through fertigation in Bt Cotton. Int. J. Curr. Microbiol. App. Sci. 6 (9), 2982, 2017. doi: https://doi.org/10.20546/ijcmas.2017.609.366

2. SULTANA J., SIDDIQUE M.A., RASHID M.H. A. Effects of cowdung and potassium on growth and yield of Kohlrabi. J. Bangladesh Agric. Univ, 10, 27, 2012.

3. FRANCIOLI D., SCHULZ E., LENTENDU G., WUBET T., BUSCOT F., REITZ, T. Mineral vs. organic amendments: microbial community structure, activity and abundance of agriculturally relevant microbes are driven by long-term fertilization strategies. Front. Microbiol. 7, 1446, 2016. doi: 10.3389/fmicb.2016.01446

4. FANG L., CHEN, L., ZHANG, J., YIN, J. AND HUANG, S. Bacterial Community Structure after Long-term Organic and Inorganic Fertilization Reveals Important Associations between Soil Nutrients and Specific Taxa Involved in Nutrient Transformations. Frontiers in Microbiology, 8, 2017.

5. JAY S.S., VIJAI K.G. Soil microbial biomass: A key soil driver in management of ecosystem functioning, Science of The Total Environment, 634, 497, 2018. https://doi. org/10.1016/j.scitotenv.2018.03.373

6. LIANG Z., HAO C., YUNQIU W., QINGGONG M., MIANHAI Z., YIRONG S., KONGCAO X., KELIN W., DEJUN L. Responses of soil microbial resource limitation to multiple fertilization strategies. Soil and Tillage Research, 196, 104474, 2020. https://doi.org/10.1016/j. still.2019.104474

7. GOMIERO T., PIMENTEL D., PAOLETTI M. G. Environmental impact of different agricultural management practices: conventional vs. organic agriculture. Crit. Rev. Plant Sci. 30, 95, 2011. doi: 10.1080/07352689.2011. 554355

8. BALDRIAN P. Microbial activity and the dynamics of ecosystem processes in forest soils. Current Opinion in Microbiology, 37, 128, 2017. https://doi.org/10.1016/j. mib.2017.06.008.

9. RAMIA J., RAINER G. J., CHRISTIAN B. Organic fertilizer effects on growth, crop yield, and soil microbial 
biomass indices in sole and intercropped peas and oats under organic farming conditions, European Journal of Agronomy, 52 (B), 259, 2014. https://doi.org/10.1016/j. eja.2013.09.001.

10. KHALID S.K., RALF M., XIOMARA C., MICHAEL K., RAINER G.J. Microbial biomass, fungal and bacterial residues, and their relationships to the soil organic matter C/N/P/S ratios, Geoderma, 271, 115, 2016. https:/doi. org/10.1016/j.geoderma.2016.02.019

11. KOOIJMAN A.M., BLOEM J., VAN DALEN B.R., KALBITZ K. Differences in activity and $\mathrm{N}$ demand between bacteria and fungi in a microcosm incubation experiment with selective inhibition. Applied Soil Ecology, 99, 29, 2016. https://doi.org/10.1016/j.apsoil.2015.11.011

12. HU Y., XIA Y., SUN Q., LIU K., CHEN X., GE T., ZHU B., ZHU Z., ZHANG Z., SU Y. Effects of long-term fertilization on phoD -harboring bacterial community in Karst soils. Sci. Total Environ. 628-629, 53, 2018.

13. CHEN H., LUO P., WEN L., YANG L., WANG K., Li D. Determinants of soil extracellular enzyme activity in a karst region, southwest China. Eur. J. Soil Biol., 80, 69, 2017.

14. [ZHU L., LI J., TAO B., HU N. Effect of different fertilization modes on soil organic carbon sequestration in paddy fields in South China: a meta-analysis. Ecol. Indic. 53, 144, 2015.

15. ZHANG Q., MIAO F., WANG Z., SHEN Y., WANG G. Effects of long-term fertilization management practices on soil microbial biomass in China's cropland: a metaanalysis. Agron. J. 109, 1183, 2017.

16. ARANCON N.Q., EDWARDS C.A., BIERMAN P., METZGER J.D., LUCHT C. Effects of vermicomposts produced from cattle manure, food waste and paper waste on the growth and yield of peppers in the field. Pedobiologia 49, 297, 2005.

17. ARANCON N.Q., EDWARDS C.A., BIERMAN P., WELCH C., METZGER J.D. Influences of vermicomposts on field strawberries: 1. Effects on growth and yields. Bioresour Technol 93, 145, 2004.

18. TIAN K., ZHAO Y., XU X., HAI N., HUANG B., DENG W. Effects of long-term fertilization and residue management on soil organic carbon changes in paddy soils of China: a meta-analysis. Agric. Ecosyst. Environ. 204, 40, 2015.

19. QIONG H., JIANLEI W., CONG W., QING W. The 19-years inorganic fertilization increased bacterial diversity and altered bacterial community composition and potential functions in a paddy soil, Applied Soil Ecology, 144, 60, 2019. https://doi.org/10.1016/j.apsoil.2019.07.009

20. AMANY A.E., KHOLOUD A.E., AZZA A.E. Effect of pre-sowing Application of Nitrogen, Potassium and Sulfur and its relationship on Egyptian Cotton Productivity. International Journal of Environment, Agriculture and Biotechnology, 2 (5), 2387, 2017.

21. PIASH M.I., FARUQUE M.H., IHUOMA N.A., SHAMIM A.M., ZAKIA P. Effect of Biochar Application on Soil Carbon Fluxes from Sequential Dry and Wet Cultivation Systems." American Journal of Climate Change 07 (01), 40, 2018. doi:10.4236/ajcc.2018.71005.

22. SPOKAS K.A., KERI B.C., JEFFREY M.N., DAVID W.A., JAMES A.I., HAROLD P.C., AKWASI A.B. Biochar: A Synthesis of Its Agronomic Impact beyond Carbon Sequestration. Journal of Environment Quality. 41 (4), 2012. The American Society of Agronomy, Crop Science Society of America, and Soil Science Society of America, Inc.: 973. doi:10.2134/jeq2011.0069.
23. MARINARI S., VITTORI A. 1. Effect of Lithological Substrate on Microbial Biomass and Enzyme Activity in Brown Soil Profiles in the Northern Apennines (Italy). Pedobiologia 53 (5). Urban \& Fischer: 313, 2010. doi:10.1016/J.PEDOBI.2010.02.004.

24. GUANG C., XIONG-MING D. Genetic Diversity of Source Germplasm of Upland Cotton in China as Determined by SSR Marker Analysis, Acta Genetica Sinica, 33 (8), 733, 2006. https://doi.org/10.1016/S0379-4172(06)60106-6.

25. LIU X. M., QI L., WEN J.L., YONG J. Distribution of Soil Enzyme Activities and Microbial Biomass Along a Latitudinal Gradient in Farmlands of Songliao Plain, Northeast China. Pedosphere, 18 (2005), 431, 2008. doi:10.1016/S1002-0160(08)60034-X.

26. TABATABAI M.A. Soil Enzymes. In: weaver, R. W., Angle, S., Bottomley, P. (Eds.), Methods of soil analysis. Part 2: Microbial and Biochemical Properties. Soil Science Society of America, Madison, 775, 1994.

27. KLAMMER R.M., KNAPP B., AICHBERGER K., INSAM H. Longterm effects of compost amendment of soil on functional and structural diversity and microbial activity. Soil Use Manag 22, 209, 2008.

28. SCHLOSS P., WESTCOTT S., RYABIN T., HALL J., HARTMANN M., HOLLISTER E., LESNIEWSKI R., OAKLEY B., PARKS, D., ROBINSON C., SAHL J., STRES B., THALLINGER, G., VAN HORN D., WEBER C. Introducing mothur: Open-Source, Platform-Independent, Community-Supported Software for Describing and Comparing Microbial Communities. Applied and Environmental Microbiology, 75 (23), 7537, 2009.

29. KUNIN V., ENGELBREKTSON A., OCHMAN H. HUGENHOLTZ P. Wrinkles in the rare biosphere: pyrosequencing errors can lead to artificial inflation of diversity estimates. Environmental Microbiology, 12 (1), 118, 2010.

30. BELOW F.E. Nitrogen metabolism and crop productivity. In: Pessarakli, M. (Ed.), Handbook of Plant and Crop Physiology Second. Marcel Dekker, Inc, New York, 385, 2001.

31. DU X., CHEN B., ZHANG Y., ZHAO W., SHEN T., ZHOU Z., MENG Y. Nitrogen use efficiency of cotton (Gossypium hirsutum L.) as influenced by wheat-cotton cropping systems. European Journal of Agronomy, 75, 72, 2016.

32. FAISAL M., IMRAN K., UMAIR A., TANVIR S., SABIR H., MUHAMMAD S., MUHAMMAD A., SAMI U. Effects of organic and inorganic manures on maize and their residual impact on soil physico-chemical properties. Journal of Soil Science and Plant Nutrition, 17 (1), 22, 2017.

33. WENWEN Z., CHONG W., MINGMING D., SHUJIE J., HUAN L. Dynamics of soil fertility and maize growth with lower environment impacts depending on a combination of organic and mineral fertilizer. Journal of Soil Science and Plant Nutrition, 18 (2), 556, 2018.

34. RAO T., WAKELIN S.A., LIANG Y., CHU G. Organic Fertilization Enhances Cotton Productivity, Nitrogen Use Efficiency, and Soil Nitrogen Fertility under Drip Irrigated Field. Agronomy Journal; Soil Fertility and Crop Nutrition, 109 (6), 2889, 2017. https://doi.org/10.2134/ agronj2017.01.005

35. SARKAR S., SINGH S.R., SINGH R.P. The effect of organic and inorganic fertilizers on soil physical condition and the productivity of a rice-lentil cropping sequence in India. The Journal of Agricultural Science, 140 (4), 419, 2003. https://doi.org/10.1017/S0021859603003186 
36. BREMNER J.M. Sources of nitrous oxide in soils. Nutr. Cycl. Agroecosyst. 49, 7, 1997.

37. CHEN W., LAU C.K., BOANSI D., BILGIN M.H. Effects of trade cost on the textile and apparel market: Evidence from Asian countries. The Journal of The Textile Institute, 108 (06, 971, 2016. doi:10.1080/00405000.2016.1206459

38. WEBB J., ELLIS S., HARRISON R., THORMAN R. Measurement of $\mathrm{N}$ fluxes and soil $\mathrm{N}$ in two arable soils in the UK. Plant Soil, 260, 253, 2004.

39. CRECCHIO C., CURCI M., MININNI R., RICCIUTI P., RUGGIERO P. Short-term effects of municipal solid waste compost amendments on soil carbon and nitrogen content, some enzyme activities and genetic diversity. Biology and Fertility of Soils, 34 (5), 311, 2001.

40. ZHOU J., GUAN D.W., ZHOU B.K., ZHAO B.S., MA M.C., QIN J. Influence of 34-years of fertilization on bacterial communities in an intensively cultivated black soil in northeast China. Soil Biol. Biochem. 90, 42, 2015. doi: 10.1016/j.soilbio.2015.07.005

41. LIANG Q., CHEN H., GONG Y., FAN M., YANG H., LAL $R$. Effects of 15 years of manure and inorganic fertilizers on soil organic carbon fractions in a wheat-maize system in the North China Plain. Nutr. Cycling Agroecosyst, 92, 21, 2012. doi: 10.1007/s10705-011-9469-6

42. PASCUAL J.A., GARCIA C., HERNANDEZ T., MORENO J.L., ROS M. Soil microbial activity as a biomarker of degradation and remediation processes. Soil Biology \& Biochemistry 32, 1877, 2000.

43. PEACOCK A.D., MULLEN M.D., RINGELBERG D.B., TYLER D.D., HEDRICK D.B., GALE P.M., WHITE D.C. Soil microbial community responses to dairy manure or ammonium nitrate applications. Soil Biology and Biochemistry 33, 1011, 2001.
44. ZHONG Y.Q., YAN W.M. SHANGGUAN Z. Impact of long-term $\mathrm{N}$ additions upon coupling between soil microbial community structure and activity, and nutrientuse efficiencies. Soil Biol. Biochem. 91, 151, 2015. doi: 10.1016/j.soilbio.2015.08.030

45. DING J.L., JIANG X., MA M.C., ZHOU B.K., GUAN D.W., ZHAO B.S. Effect of 35 years inorganic fertilizer and manure amendment on structure of bacterial and archaeal communities in black soil of northeast China. Appl. Soil Ecol. 105, 187, 2016. doi: 10.1016/j.apsoil.2016.04.010

46. LIN B., ZHAO H. Technological progress and energy rebound effect in China's textile industry: Evidence and policy implications. Renewable and Sustainable Energy Reviews, 60 (C), 173, 2016. doi: 10.1016/j.rser.2016.01.069

47. KURAMAE E., YERGEAU E., WONG L., PIJL A., VEEN J., KOWALCHUK G. Soil characteristics more strongly influence soil bacterial communities than landuse type. FEMS Microbiology Ecology, 79 (1), 12, 2012.

48. HUANG W., BAI Z., HOEFEL D., HU Q., LV X., ZHUANG G., XU S., QI H., ZHANG H. Effects of cotton straw amendment on soil fertility and microbial communities. Frontiers of Environmental Science \& Engineering, 6 (3), 336, 2012.

49. NAVARRETE A.A., SOARES T., ROSSETTO R., VAN VEEN J.A., TSAI S.M., KURAMAE E.E. Verrucomicrobial community structure and abundance as indicators for changes in chemical factors linked to soil fertility. Antonie van Leeuwenhoek, 108 (3), 741, 2015.

50. CHAPARRO J., SHEFLIN A., MANTER D., VIVANCO J. Manipulating the soil microbiome to increase soil health and plant fertility. Biology and Fertility of Soils, 48 (5), 489, 2012. 